\title{
DOCTOR OF MEDICINE AND DIPLOMATE OF NATIONAL BOARD COURSES IN INDIA-ISSUES AND EQUIVALENCE: A COMPARATIVE ANALYSIS
}

\section{ANUSUYA BHATTACHARYYA ${ }^{1 *}$, PHULEN SARMA ${ }^{2}$, HARISH KUMAR ${ }^{2}$, BIKASH MEDHI ${ }^{2}$, KASTURI BHATTACHARJEE ${ }^{1}$, HARSHA BHATTACHARJEE ${ }^{1}$, SUBODH KUMAR ${ }^{2}$, SIRIS KR BHATTACHARYYA ${ }^{3}$, DILIP VAISHNAV ${ }^{4}$}

\begin{abstract}
${ }^{1}$ Department of Ophthalmology, Sri Sankaradeva Nethralaya, Guwahati, Assam, India. ${ }^{2}$ Deparment of Pharmacology, Post Graduate Institute of Medical Education and Research, Chandigarh, India. ${ }^{3}$ Department of English, Sivasagar Girls' college, Sivasagar, Assam, India. ${ }^{4}$ Department of Forensic Medicine, Post Graduate Institute of Medical Education and Research, Chandigarh, India. Email: anusuya.8k@gmail.com
\end{abstract}

Received: 29 October 2019, Revised and Accepted: 31 December 2019

\section{ABSTRACT}

India is the only country in the world running two different doctoral courses for doctors, i.e., Doctor of Medicine (MD) and Diplomate of National Board (DNB). DNB course was introduced in 1975 to overcome shortage of specialist doctors and medical teachers. Both courses have centralized entry examination, similar tenure period, academic and clinical activities, and research exposure and exit examination (in the host institute in MD examination and in designated exit exam centre in institute other than poarent institute in case of DNB examination). Initially, the Ministry of Health and Family Welfare and Medical Council of India (MCI) established the equivalence between two. Discrimination started since October 2012 through MCI gazette notification for DNB trainees from non-MCI recognized institutes with regards to teacher appointment. DNB doctors were united to raise their voice against this. While the Government of India (GOI) is in favor of equivalence between two, MCI is against the same. Recently, MCI is dissolved and is going to be replaced by the National Medical Commission and positive outcome is expected for the DNB side. A recent notification is issued toward equivalence of two courses provided candidate completed DNB course from hospitals with minimum 500 beds. Evaluating quality of education on the basis of number of beds seems unjustifiable as there are many better indicators of quality of medical education. The NMC act also retained the same 500 bed criteria. Taking into account the view point of benefit of population and improvement in medical education in India, it is desirable to reconsider the issue by the Government of India (GOI) and to act accordingly. To enhance the standard of current medical education, higher standards should be imposed in curriculum and centralized exit examination to be made compulsory for both the courses.

Keywords: Diplomate of National Board, Doctor of Medicine, Equivalence.

\section{INTRODUCTION}

India is the only country in the world running two different doctoral courses for doctors, i.e., Doctor of Medicine (MD) and Diplomate of National Board (DNB) [1]. Earlier, DNB qualification was considered equivalent to MD course including medical teacher appointment [2]. However, due to certain issues raised by Medical Council of India (MCI), DNB holders from non-MCI recognized institutes face limitations regarding medical teacher appointment $[3,4]$. In this article, we are trying to analyze these issues and their practical relevance.

\section{A BRIEF HISTORY: MCI/MD COURSES}

MCI was established (1934) under "The Indian Medical Council Act (IMCA) 1933" with the objective of establishing uniform standards in higher medical education, recognition of Indian medical degree, and from abroad [5]. The purpose of MD course was to create high-quality specialist for Indian health-care system, training and research promotion [5]. For medical teacher (MD/Master of Surgery [MS]/Bachelor of Medicine and Bachelor of Surgery [MBBS]) appointment, the eligibility criteria are governed by "MCI guidelines" by "The Post-graduate Medical Education Committee" (IMCA, 1956 Section 20) [6]

\section{HISTORY OF NATIONAL BOARD OF EXAMINATIONS (NBE) AND DNB COURSES}

The objective to establish NBE was to improve the quality and uniformity of medical education, upliftment of postgraduate (PG) examination standard, produce efficient specialist [7,8]. In 1982, NBE became an independent body under the Ministry of Health and Family
Welfare (MOHFW) having the power of accreditation of hospitals and institutions to train medical doctoral (DNB broad specialty) and post-doctoral (DNB superspecialty) degrees with around 42 medical disciplines currently under edges $[7,8]$.

\section{TIMELINES OF DNB COURSE}

In November 19, 1983, MOHFW notified that a DNB qualification granted on or after August 30,1982, will be a recognized medical qualification [2]. In October 3, 1994, MOHFW declared that DNB holders (in the broad specialties) should have at least 1 year teaching experience (Tutor/Registrar/Demonstrator or equivalent post) in a recognized medical college which are running MBBS course for medical teacher appointments [9]. In June 1, 2006, MOHFW modified that DNB qualification awarded by NBE is equivalent as MD/MS with respect to medical teacher appointment [10]. In February 20, 2009, MOHFW clarified that DNB is equivalent to MD/MS in all respect and DNB training period will be treated as teaching experience [11]. The timelines of different developments are shown in Table 1.

\section{MD-DNB EQUIVALENCE AND CONFLICT, MCI TEACHERS ELIGIBILITY CRITERIA}

Although MOHFW notifications No.V11015/17/83-ME dated September 19, 1983 [12], No.V.11025/13/2004-MEP-(I) Government of India (GOI) dated June 1, 2006 [10], No.V.11025/12/2004-MEP-(I) (GOI) [11] dated February 20, 2009, No.V.11012/1/2014-MEPI dated December 10, 2014 [13], No.V.11012/1/2014-MEPI [14] dated June 30, 2014, and No.V.11012/1/2014-MEPI [15] dated May 12, 2017, established the equivalence between MD and DNB courses, still many a times, discrimination is noted between them. 
Table 1: Timeline of events of DNB course

\begin{tabular}{|c|c|c|c|}
\hline Year & Event & Notification details & Reference \\
\hline 1983 & $\begin{array}{l}\text { The Diplomate of National Board qualification in } \\
\text { various disciplines granted by the NBE, New Delhi, } \\
\text { shall be recognized medical qualifications when } \\
\text { granted on or after August 30,1982 }\end{array}$ & $\begin{array}{l}\text { Ministry of Health and Family Welfare, notice } \\
\text { no. No. V 11015/17/83-ME. dated November } \\
\text { 19, } 1983\end{array}$ & {$[12]$} \\
\hline 1994 & $\begin{array}{l}\text { For teaching appointments in the broad specialties } \\
\text { the holder of Diplomate NBE should have at least } \\
1 \text { year teaching experience as tutor/registrar/ } \\
\text { demonstrator or equivalent post in a recognized } \\
\text { medical college imparting undergraduate teaching } \\
\text { and training for appointment as lecturer }\end{array}$ & $\begin{array}{l}\text { GOI } \\
\text { Ministry of Health and Family Welfare } \\
\text { Notice no No.V.11025/6/94-ME (UG) dated } \\
\text { October 3, } 1994\end{array}$ & [9] \\
\hline 2006 & $\begin{array}{l}\text { DNB qualification awarded by the National Board of } \\
\text { Examinations Equivalence of Board's qualification for } \\
\text { appointment as teachers }\end{array}$ & $\begin{array}{l}\text { GOI } \\
\text { Ministry of Health and Family Welfare, New } \\
\text { Delhi, Notice no No.V.11025/13/2004-MEP-(I) } \\
\text { dated June 1, } 2006\end{array}$ & [10] \\
\hline 2009 & $\begin{array}{l}\text { DNB is equivalent to MD/MS and DNB training period } \\
\text { will be treated as teaching experience }\end{array}$ & $\begin{array}{l}\text { Notice No.V.11025/12/2004-MEP-(I) (GOI) } \\
\text { Ministry of Health and Family Welfare, New } \\
\text { Delhi, dated February 20, } 2009\end{array}$ & [11] \\
\hline November 4,2010 & DNB is equivalent to MD/MS & $\begin{array}{l}\text { MCI Notification No. 04/11/201003/11/2010 } \\
\text { MCI dated November 4, 2010 Med. } \\
\text { Misc./33038(1) Minimum Qualifications for } \\
\text { Teachers in Medical Institutions Regulations, } \\
1998\end{array}$ & {$[20]$} \\
\hline June 11, 2012 & Extra 1 year senior residency for MD/MS equivalence & $\begin{array}{l}\text { Notice No.MCI-12(2)/2010-Med.misc dated } \\
\text { June 11, } 2012\end{array}$ & [16] \\
\hline June 30,2014 & $\begin{array}{l}\text { Direction to President, MCI regarding unauthorized } \\
\text { circular to medical institutions }\end{array}$ & $\begin{array}{l}\text { No.V.11012/1/2014-MEPI, GOI, MOHFW, } \\
\text { Direction to President, MCI regarding } \\
\text { unauthorized circular to medical institutions, } \\
\text { dated June } 30,2014\end{array}$ & [18] \\
\hline December 10, 2014 & $\begin{array}{l}\text { Letter from GOI, MOHFW, assuring MD/MS and DNB } \\
\text { equivalence, DNB representative }\end{array}$ & $\begin{array}{l}\text { No.V.11012/1/2014-MEPI, GOI, MOHFW } \\
\text { dated December 10, } 2014\end{array}$ & [13] \\
\hline May 12, 2017 & $\begin{array}{l}\text { To comply with existing order to consider DNB } \\
\text { equivalent to MD/MS }\end{array}$ & $\begin{array}{l}\text { No.V.11012/1/2014-MEPI, GOI, MOHFW } \\
\text { dated May 12, } 2017\end{array}$ & [14] \\
\hline
\end{tabular}

DNB: Diplomate of National Board, NBE: National Board of Examination, MCI: Medical Council of India, MD: Doctor of Medicine, MS: Master of Surgery, MOHFW: Ministry of Health and Family Welfare, GOI: Government of India

The conflict starts to appear in news since June 11, 2012, vide notice No.MCI-12(2)/2010-Med.Misc [16]. MCI started MD-DNB discrimination in Medical Council gazette notification (Amendment notification) by putting extra 1 year and 2-year senior residency as teaching experience (tutor/registrar/demonstrator or an equivalent post) in an MCI recognized medical college running MBBS and MD/MS course for equivalence for teaching appointment [16].

MCI raised certain issues (Notification.No.MCI-12(1)/2017-Med Misc./115698/5.06.2017) for DNBs from non-MCI recognized institution and clearly stated extra 1 year and 2-year senior residency for MD/MS equivalence $[3,4]$ in broad specialty and superspecialty contradictory to the previous order of GOI [17]. MOHFW questioned MCI this unauthorize decision [18] and declared MCI order as void $\mathrm{ab}$ initio [19]. However, further notices from MCI continued creating confusion regarding teaching appointment of DNB doctors [19]. DNB doctors united to raise their voice against the injustice and monopoly of MCI through the Association of National Board Accredited Institutions and communicated MOHFW, MCI, and honorable Prime Minister Office (PMO) regarding the issue [19]. MOHFW (Notice NoV.11012/1/2014MEPI.GOI) ordered MCI to issue advisory for medical colleges to comply with the existing regulations and the issue was declared closed $[18,20]$. However, MCI disobeyed MOHFW through the order of Teacher Eligibility Criteria (TEQ) subcommittee letter $[3,4]$ and discrimination continued [19], no mention was found regarding DNB qualification in Gazette of India notification $[3,4,19]$. MCI gave specific reasons why DNB qualification cannot be equivalent to MD/MS and DM/M. Ch degrees through media [21,22] with clear extra 3 years junior residency for DNBs mentioned in "Teacher's eligibility Qualification regulation" (amended vide notification NO. MCI-12(1)/2017Med. Misc./115698) [23] and frequently asked questions (FAQs) in official MCI website $[19,23]$

\section{VERSUS DNB FOR ASSISTANT PROFESSOR IN MEDICAL COLLEGES}

According to MCI "minimum qualification for MCI, Minimum Qualifications for Teachers in Medical Institutions Regulations, 1998 (amended up to June 8, 2017) guideline" to make a DNB candidate eligible for medical teacher following criteria to be followed [4]: For DNB holders from MCI recognized medical colleges/central institutes running MD/MS courses 3 years teaching experience in the subject either during the DNB course or after obtaining DNB qualification, for DNBs from MCI recognized medical colleges/central institutes without MD/MS courses: Three years teaching experience in the subject in an MCI recognized institute either during the tenure or after obtaining degree and also additional 1 year teaching/research experience in an MCI recognized institute after obtaining degree, and for candidates other than above-mentioned institute: Additional 3 years teaching experience is required along with 2 years additional teaching 
experience as Sr. Resident/Research Associate Council of Scientific and Industrial Research (CSIR) in an MCI recognized institute [4] plus minimum two publications (accepted/published) in the index journal (national/international as the first/second author). In case, the candidate do not have the required publication, must have total 3 years teaching experience in an MCI recognized institute after possessing DNB qualification [4].

\section{COMPARISON OF MD AND DNB DEGREE}

Entry examination for both DNB and MD/MS program is through a national level centralized entrance test (Combined NEET PG entrance by NBE) with centralized counseling. Duration of both the courses is 3 years, run in both government and private set up with similar quality standard of the host institute [21,24], similar academic activities, compulsory thesis work of 1 year duration under a qualified thesis guide with external review process (exposure to research methodology), and academic activities (library and journal facility, presentation in national and international conferences, research article publication, training program, workshop, and CME). Clinical activity in both the courses is similar with respect to emergency case handling, surgical exposure, clinical case discussion, case exposure, availability of equipment and diagnostic tool, patient load to be handled, duty hour, night duty, leave entitled including maternity leave and other facilities. Regarding the exit examination, in MD course, theory and practical examination is conducted in host institute; in practical examination, both internal (high chance of bias in evaluation process) and external examiners are present. Furthermore, passing theory examination is not an essential criterion of eligibility to appear in the practical examination. While DNB exit examination is an unbiased, extremely tough evaluation process both in theory and practical (conducted in different center without the presence of internal examiner) with only $30-35 \%$ pass percentage $[21,24]$. Passing theory examination is essential criteria to appear in practical examination showing superiority of the DNB candidates (detail comparison of both the courses is given in Table 2).

As at the time of entry to the course, the courses were equivalent (also equivalent as per government norms) and students joined DNB even leaving PG seats in MD/MS course to get their branch of interest. Suddenly making non-equivalent is injustice to the students who joined DNB course. In earlier job interviews, the advertisements mentioned MD/MS/DNB, which implied their equivalence in government settings. Many DNB students are working as faculty in Government Medical Colleges and they are holding important positions in medical college as clinician and academician.

\section{TEACHING EXPERIENCE: THE DEBATE}

According to a former academic chairman of MCI [21], MCI is against MD/MS and DNB equivalence unless DNB degree holder has extra 1 year teaching experience along with 3 years of tutorship from a MCI recognized institute of concern specialty. According to him, undergraduate teaching during MD/MS tenure during PG is counted as "teaching experience" which is not seen in non-teaching hospitals [21]. However, in many premier institutes, for example, Post Graduate Institute of Medical Education and Research, Chandigarh, Bombay Hospital, Mumbai, TATA Memorial, Mumbai, Institute of Mental Health, Agra, Institute of Naval Medicine, INHS Asvini, Mumbai, Regional Cancer Hospital, Agartala, and Regional Cancer Hospital, Trivandrum, there is no MBBS training program but the teaching experience in these institutes is recognized by MCI. The high class academic environment in these institutes depends on high number of seminars, journal clubs, CME/workshop/symposiums, and practical demonstrations. These central institutes are issuing teaching certificate, which is valid all over India on the basis of MBBS teaching but on the basis of procedural activities, academic (clinical case discussion, seminar, journal club etc.) and research activity.

Similarly, in many DNB institutes being superspecialty hospitals, although no undergraduate teaching is there, high-level academic and research activity should be the evaluation criteria. Again, if a doctor can teach MD/MS/MCH/DM/DNB (specialty)/DNB (superspecialty), undergraduate teaching is a very simple experience for them and discriminating DNBs from MD/MS on the basis of undergraduate teaching are a deficient evaluation system and mere injustice. Again, MCI recognizes MD/MS degree obtained from institutes outside India, by simply allowing them to appear in an entry examination. It is to be noted that in many of the foreign institutes, there is no undergraduate teaching. Hence, if MD/MS tenure is applicable for teaching certificate in MD/MS course then why same not applicable to DNB. In 2009, MOHFW through notification no. S.0.522(E) (20.02.2009) established the equivalence between MD and DNB and recognized and ordered DNB training period to be treated as teaching experience, many DNB institutes do not issue teaching certificate, which is violation of the order of MOHFW [17].

Interestingly, is also seen that, many private medical colleges are compromised in quality, do not have requisite patient load, and use fake patient during MCI inspection leading to low-quality workforce production. AIIMS junior doctor has launched a campaign against this [25]. It is strange that $\mathrm{MCI}$, on the one hand, recognizing MD/MS from these institutes, which is supposed to generate poorquality medicos while not recognizing high-quality DNB degree holders which is a matter of concern and intention is unknown.

\section{BED REQUIREMENT CRITERIA: FALLACIES: HIGH-TECH ENVIRONMENT/HIGH NUMBER OF BEDS}

In this era of superspecialty, some of the hospitals are dedicated to one particular superspecialty (e.g., ophthalmology/urology/neurosurgery). Minimum number of bed criteria (Arbitrary 500-bed criteria) laid down by MCI for overall hospital is practically not feasible in superspecialty hospital setting. If we see some MCI recognized hospitals, where some specialty branches are running with very few beds, but the overall beds (including all stream/specialty branches) are 500. Hence, for an ophthalmology trainee, the overall hospital beds (say beds in psychiatry) matter less than that of bed in ophthalmology. The most important is number of beds available in ophthalmology. In India, none of the hospitals have 500 beds dedicated to ophthalmology. Furthermore, point to be noted that, in the present era of precision for example ophthalmic service, most of the surgery is done either as day care or as office procedure. Only $2-5 \%$ of the patient may require hospitalization. In that case, only few indoor beds are necessary which are also applicable to specialties other than ophthalmology.

\section{INDICATORS OF QUALITY OF MEDICAL EDUCATION}

Important indicators of health-care education are reviewed and used by many authors and outcome assessment indicators should be valid, reliable, and repeatable [26]. We have lots of better quality indicators of medical education rather than number of beds which can be divided into educational, research, and social accountability quality indicators [26-29]. Examples of indicators of quality of healthcare institutions are research assessment exercise - 2008, income from research grant/contracts, number of students selected for higher degree, number of patents granted, number of high-quality publications in peer-reviewed indexed journals, student feedback survey (mainly final year students) regarding quality of their course, teacher-student ratio, clinical competence, etc. [27]. Hence, simply assumption of quality of medical education on the basis of number of beds is scientifically not justifiable.

\section{TEQ EVALUATION BODY AND REPRESENTATION OF DNBS}

Whether in the MCI body (deciding the equivalence of MD/MS and DNBs) was there any DNB representative or opinion of NBE was taken is another matter of debate. There is a need for harmonization of both the courses (e.g., master level [M.Sc. degree and MBBS degree are considered equivalent], doctorate level [MD/MS/DNB broad specialty], and postdoctorate level [DM/MCH/DNB superspecialty]) and updation 
Table 2: Comparison between MD and DNB courses

\begin{tabular}{|c|c|c|c|}
\hline Criteria & Subcriteria & MD/MS & DNB \\
\hline \multirow[t]{6}{*}{ Joining criteria } & Joining in DNB & After MBBS & After MBBS \\
\hline & & $\begin{array}{l}\text { Centrally conducted entrance } \\
\text { examination }\end{array}$ & Centrally conducted entrance examination \\
\hline & & Centrally conducted counseling & Centrally conducted counseling for admission \\
\hline & & NET board & NET board \\
\hline & Duration & 3 years & 3 years \\
\hline & Postdiploma courses & 2 years & 2 years \\
\hline Host institutes & Quality of host institutes & $\begin{array}{l}\text { Government Medical Colleges: good } \\
\text { private medical colleges: Many are very } \\
\text { good, but many are of questionable quality } \\
\text { with very less patient load }\end{array}$ & $\begin{array}{l}\text { Government Institutes: Good } \\
\text { private institutes: Very good with high end } \\
\text { facilities and patient load, as the NET board is } \\
\text { very stringent regarding the institutes }\end{array}$ \\
\hline Academic & Departmental Journal clubs & Yes & Yes \\
\hline \multirow[t]{5}{*}{ activity } & $\begin{array}{l}\text { Journal club presentation by } \\
\text { candidates }\end{array}$ & Yes & Yes \\
\hline & Departmental seminars & Yes & Yes \\
\hline & $\begin{array}{l}\text { Case presentation and } \\
\text { discussion }\end{array}$ & Yes & Yes \\
\hline & Library and journal facility & Yes & Yes \\
\hline & Attending CME & Yes & Yes \\
\hline \multirow[t]{5}{*}{ Thesis work } & Number of thesis & 1 & 1 \\
\hline & Ethical clearance & Required & Required \\
\hline & Quality of thesis & Similar & Similar \\
\hline & External review of thesis & Yes & Yes \\
\hline & $\begin{array}{l}\text { Thesis is an important part of } \\
\text { academic activity }\end{array}$ & Yes & Yes \\
\hline \multirow[t]{3}{*}{ Thesis guide } & Educational status of guide & MD/MS/DNB or above & $\mathrm{MD} / \mathrm{MS} / \mathrm{DNB}$ or above \\
\hline & $\begin{array}{l}\text { Clinical expertise and } \\
\text { knowledge of the guide }\end{array}$ & $\begin{array}{l}\text { As the promotion is time duration based, } \\
\text { and is non-dependent on the expertise or } \\
\text { clinical accuracy, anybody doing job for a } \\
\text { reasonable degree of time can be a guide }\end{array}$ & $\begin{array}{l}\text { In DNB settings, as promotion and other activities } \\
\text { in private sectors are dependent on clinical } \\
\text { expertise or performance in the respective field, } \\
\text { only faculty with high quality can be guide }\end{array}$ \\
\hline & Final examination examiner & $\begin{array}{l}\text { Internal and external. As the internal } \\
\text { examiner is from the same institute, high } \\
\text { chance of bias in examination results and } \\
\text { proper evaluation of the candidate }\end{array}$ & $\begin{array}{l}\text { Only external, no internal. This ensures no bias } \\
\text { in examination result and proper evaluation of } \\
\text { the candidate and only eligible candidates pass }\end{array}$ \\
\hline \multirow{8}{*}{$\begin{array}{l}\text { Clinical activity } \\
\text { equivalence }\end{array}$} & Emergency case handling & Yes & Yes \\
\hline & Surgical exposure & Similar & Similar \\
\hline & Clinical case discussion & Yes & Yes \\
\hline & Case exposure & Yes & Yes \\
\hline & $\begin{array}{l}\text { Availability of equipment and } \\
\text { diagnostic tool }\end{array}$ & Similar & Similar \\
\hline & Patient load to be handled & Similar & Similar \\
\hline & Night duty & Yes & Yes \\
\hline & Ward facilities & Yes & Yes \\
\hline Teaching skill & & Similar to DNB & $\begin{array}{l}\text { Similar to MD. Many DNBs are already doing } \\
\text { very well at par their MD colleagues as medical } \\
\text { teacher in many medical institutes of repute. }\end{array}$ \\
\hline Practitioner skill & & No difference with DNB & No difference with MD \\
\hline
\end{tabular}

DNB: Diplomate of National Board, MD: Doctor of Medicine, MS: Master of Surgery, MBBS: Bachelor of Medicine and Bachelor of Surgery, NET: National Eligibility Test

of curriculum as per world standard at definite time intervals $\mathrm{MCI}$ should have come forward for a harmonized medical system in India.

\section{CASE STUDY: OPHTHALMOLOGY TRAINING IN INDIA MD/MS VERSUS DNB}

The most equipped eye hospitals cum training center in India have $<500$ beds (Shankara Nethralaya [Chennai, Kolkata], Sri Sankaradeva Nethralaya, Guwahati [declared Centre of Excellence by honorable PMO Dr. Manmohan Singh] [30], LVPEI [Hyderabad, Bhubaneshwar], Narayana Nethralaya [Bengaluru], Sankara Eye Hospital [Bengaluru], etc.) where post-MD/MS doctors come for advanced training from MCI recognized institute (similarly in other specialties). Hence, it is not the number of beds, but the high-quality academic and research environment and surgical exposure and annual load of cases of the institute.

\section{STAND OF HONORABLE SUPREME COURT OF INDIA}

Major setback was observed for DNBs when the Honorable Supreme Court of India dismissed the filed petition by Sankalp Association of DNB Doctors demanding complete MD-DNB equivalence for medical teacher appointment in India (Petition against MCI notification Minimum 
Qualifications for Teachers in Medical Institutions Regulations, 1998 rules [June 5, 2017] extra 3-year junior residency and 2-year senior residency for DNBs of non-MCI recognized institute) [31,32].

\section{STAND OF GOI ON THE ISSUE}

As obvious in the timeline events (Table 1), it seems that GOI is interested in solving the issue between MOHFW and MCI. National Medical Commission bill (NMC bill) seems to be in favor of establishing MD-DNB equivalence and trying to bring all UG/PG medical courses under same umbrella [33,34]. Recently, replacement of MCI by NMC is a revolutionary step toward solving the issue (contrary to MCI members elected within medical community, 25 members proposed agency appointed by GOI) [35-38]. The NMC bill also addresses acute shortages of medical personnel in India, by proposing three approaches: (1) Replacing continuous inspections of infrastructure/personnel by accreditation (eliminating threat of closure of medical colleges on flimsy grounds), (2) entry of new colleges, and (3) allowing automatic expansion of seats up to 250 in the existing provided acceptable standards maintained [38]. It establishes full parity between DNB degree by NBE and PG and $\mathrm{DM} / \mathrm{MCH}$ degrees under NMC which preserves the independence of NBE and gateway to DNBs for medical teacher appointment [38] also gives freedom to medical colleges to start PG courses. Competition between NBE and NMC blessed PGs will also bring pressure to improve quality standards in PG education on two entities.

In a recent notice (No V.11025/16/2016-MEP, 6.09.2018, GOI [MOHFW]), MD-DNB equivalence under NMC bill, 2017, was addressed in LOK Sabha has been amended after considering recommendations of Parliamentary Standing Committee (109 $9^{\text {th }}$ report) on Health and Family Welfare and MD-DNB equivalence is proposed including teaching. The amendment states that the DNB qualification from institute with minimum 500-bed shall be equivalent in all respect to $\mathrm{MD} / \mathrm{MS}$ and all for other cases, additional 1-year senior residency in a MCI recognized medical college shall be required for equivalence [39]. In a twitter (October 19, 2019) with Association of DNB Doctors, Delhi High Court gave opinion by addressing the issue, "DNB hospitals are teaching hospitals and DNBs trained in these hospitals can hold teaching posts." [40] The new MCI Board of Governors (MCI-BOG) approved these major relaxations and also removed the previous criteria of not considering 3-year tenure period as teaching experience (DNBs from non-MCI recognized institute) [41] and through "Minimum Qualifications for Teachers in Medical Institutions (Amendment) Regulations, 2018," this will be effective from October 31, 2018 [42,43] Although it is circulated various internet sources that, "DNB holders of Broad Specialties and Super Specialties course completing from institutions $\geq 100$ beds are required to undergo additional 1-year senior residency in a MCI recognized/permitted institution for MD/MS/ DM/M.Ch equivalence for teaching appointment", it is not incorporated till date and 500 bed criteria is still the essential criteria [44-46].

In the Minimum Qualifications for Teachers in Medical Institutions Regulations, 1998 (as amended upto 8th June, 2017), MD and DND was considered equivalent if it was done from a MCI recognized institute, which run postgraduate courses or those who have undergone DNB training in a multispecialty hospital with 500 or more beds. In other case, they will need one additional year of residency in MCI recognized medical college [35].

\section{NMC BILL AND MD-DNB EQUIVALENCE}

In the NMC Act, MD-DNB complete equivalent is addressed [47] and clear justification is given regarding shortage of medical faculties, justification of running two parallel courses (MD and DNB) in the FAQs portion answers is given clearly regarding the issues of. Importance of DNB for post-graduation course in smaller town also highlighted (MOHFW/public notice/50 major FAQs/NMC bill) [47]. In the National medical council act-2019 (NMC act- $8^{\text {th }}$ August, 2019) MD and DNB are considered equivalent if it is done in a medical institution with an attached hospital or in hospital with a bed strength of 500 or more.
In this case, both the degrees will be totally equivalent. In other case, an additional one year senior residency in a medical college will be the necessary criteria for equivalence for the purpose of teaching in medical college [48]

\section{EXPERT OPINION REGARDING MD-DNB EQUIVALENCE}

Many medical experts recommend DNB as the most non-corrupt entry and exit examination in India in the present days while some are against it [21,24,35]. A well-known Professor from Manipal Academy of Higher Education support regarding MD-DNB equivalence issue stating "Welcome decision" by stating DNB examination standards to be "superior" with "no home ground advantage". [24]. Many senior academicians consider that DNB is equivalent/superior to MD/MS with respect to training/practice ability stating high standard and noncorrupt system in India [24]. They also expressed that training/skill sets vary in different institution both in DNB and MD course. Another medical expert also considers superiority of DNB over MD/MS by addressing its high standard, centralized selection procedure, tough exit examination, increase reorganization in abroad, and support toward MD-DNB equivalence [21]. Another medical expert pointed out that although requirement of additional experience was reasonable earlier for DNBs due to lake of dissertation/thesis, but now since compulsory thesis work is included in curriculum, there is no rationale for additional teaching experience [24].

\section{DNB (DIPLOMATE OF NATIONAL BOARD): DIPLOMATE VERSUS DOCTORATE}

DNB is done post-MBBS. As we know, MBBS course is equivalent to MSc, $\mathrm{MD}$ is considered as a doctoral degree at par with $\mathrm{PhD}$ [49] and duration of MD/Ph.D/DNB course is similar (3 years). Hence, we suggest the term "Diplomate' to be removed by "Doctorate," which will help in harmonization of the different medical education system in India

\section{CONCLUSION AND SUGGESTION}

By enabling the large number of DNB qualified doctors to enter health-care system would help to overcome the shortage of specialists and medical teacher. Regarding teaching experience, GOI has already clarified that DNB training period to be treated as teaching experience. Regarding requirement of additional teaching experience for DNB residents seems unjustified as similar performance in academic and clinical activity of both courses is comparable. Mere differentiating MDs and DNB on arbitrary bed criteria also seem to be flawed, as there are lots of better indicator of quality of education. Hence, we urge that MDs and DNBs are comparable and equivalent in all means and they should be treated as such. However, our suggestion is that leaving the divide and rule policy, government should act to enhance the standard of current medical education, higher standards should be imposed on both MD and DNB curriculum, MD exit examination should be unbiased (preferably in a different place than place of training), which will decrease in evaluation bias in the examinations and will ensure us quality manpower. At present, MCI is replaced with a seven-member BOG which has been appointed for an initial 1 -year period and will be the sole decision-making body until the NMC bill [50]. Hence, we are waiting for positive environment in Indian health-care education system and the ultimate beneficiary should be Indian population.

\section{ACKNOWLEDGMENT}

Nil.

\section{CONFLICTS OF INTEREST}

None of the authors declared any conflicts of interest.

\section{FUNDING}

Nil. 


\section{DISCLOSURE}

The study is not funded by any agency or company. It is solely investor initiated study.

\section{REFERENCES}

1. $\mathrm{DNB}$ or $\mathrm{MD} / \mathrm{MS}$ ? Which One is better after MBBS in the Indian Scenario? Mountain View: Quora; 2019. Available from: https://www. quora.com/dnb-or-md-ms-which-one-is-better-after-mbbs-in-theIndian-scenario. [Last accessed on 2019 Jul 14].

2. National Board of Examination. No. 5 11015/17/83-ME. Policy, Government of India Ministry of Health and Family Welfare (Department of Health). Available from: https://www.natboard.edu.in/ dnb matter.php?notice id=4.

3. Gazette of India, (Amendment Notification). Available from: https:// www.mciindia.org/documents/e gazette amendments/teq. [Last accessed on 2017 Jun 08]

4. Minimum Qualifications for Teachers in Medical Institutions Regulations; 1998. Substitution of clause 6 in schedule. Available from: https://www.mciindia.org/documents/e Gazette Amendments/ TEQ-08.06.2017.pdf. [Last accessed on 2019 Sep 01].

5. MCI. Available from: https://www.old.mciindia.org/aboutmci/ introduction.aspx. [Last accessed on $2019 \mathrm{Jul} 09$ ].

6. The Indian Medical Council Act. Act No. 102; 1956. Available from https://www.indiacode.nic.in/bitstream/123456789/1650/3/A1956102.pdf.

7. Guidelines for Competency Based Training Programme in DNB Family Medicine; 2019. Available from: https://www.nbe.edu.in/mainpdf/ curriculum/Family-Medicine.pdf.

8. Guidelines for Competency Based Training Programme in DNB Ophthalmology. Available from: https://www.nbe.edu.in/mainpdf/ curriculum/ophthalmology.pdf.

9. Government of India Ministry of Health and Family Welfare Welcome to National Board of Examination. No. 5. 11025/6/94-ME (UG). Available from: https://www.natboard.edu.in/dnb matter.php?notice id=5. [Last accessed on 2019 Jul 09].

10. National board of examinations. No. 5. 11025/13/2004-ME(P-I) Government of India Ministry of Health and Family Welfare, Department of Health and Family Welfare; 2006. Available from: https://www.natboard.edu.in/dnb_matter.php?notice_id=7. [Last accessed on 2019 Jul 09].

11. Government of India Ministry of Health and Family Welfare, Department of Health and Family Welfare. National Board of Examination; 2009. Available from: https://www.natboard.edu.in/dnb matter.php?notice id=9.

12. Policy Government of India Ministry of Health and Family Welfare (Department of Health) Welcome To National Board of Examination. No. 5. 11015/17/83-ME. Available from: https://www.natboard.edu.in/ dnb_matter.php?notice_id=4. [Last accessed on 2019 Jul 09]

13. Government of India, Ministry of Health and Family Welfare, Direction to President, MCI Regarding Unauthorized Circular to Medical Institutions. National Board of Examinations. No. 5 11012/1/2014-MEPI; 2014. Available from: https:/www.natboard.edu. in/pdoof/equivalence300614.pdf.

14. GOI, MOHFW, Letter from Government of India, Ministry of Health and Family Welfare, Assuring MD/MS and DNB Equivalence. National Board of Examinations. No. 5. 11012/1/2014-MEPI; 2014. Available from: https://www.natboard.edu.in/pdoof/scan1101.pdf.

15. GOI, MOHFW, National Board of Examination. No. 5. 11012/1/2014 MEPI. Available from: https://www.natboard.edu.in/dnb notice board/ notice file/dnb\%20qualification.pdf. [Last accessed on 2017 May 12].

16. The Gazette of India. Available from: https://www.natboard.edu.in/ dnb notice board/notice file/the gazette of india[1] pdf. [Las accessed on 2019 Jul 09].

17. Government of India Ministry of Health and Family Welfare, Department of Health and Family Welfare, Welcome to National Board of Examination. No. 5. 11025/12/2004-MEP-(1). Available from: https://www.natboard.edu.in/dnb_matter.php?notice_id=9. [Last accessed on 2019 Jul 09].

18. Equivalence 300614. Available from: https://www.natboard.edu.in/ pdoof/equivalence300614.pdf. [Last accessed on 2019 Jul 09].

19. DNB Equivalence Matter Association of DNB Doctors (ADD) Wrote to Nadda JP. Medical Reporter Today; 2018. Available from: https://www.medicalreportertoday.com/dnb-equivalence-matterassociation-of-dnb-doctors-add-wrote-to-j-p-nadda. [Last accessed on 2019 Jul 09]

20. Scan 1101. Available from: https://www.natboard.edu.in/pdoof/ scan1101.pdf. [Last accessed on 2019 Jul 09].

21. MCI too against Equating DNB with MD Nagpur News Times of India. Available from: https://www.timesofindia.indiatimes.com/city/nagpur/ mci-too-againstequating-dnb-with-md/articleshow/7565244.cms. [Last accessed on 2019 Jul 10].

22. DNB Equivalent to MD? Doctors Divided the New Indian Express. Available from: http:/www.newindianexpress.com states/karnataka/2018/mar/27/dnb-equivalent-to-md-doctorsdivided-1792940.html. [Last accessed on 2019 Jul 10].

23. FAQ-TEQ. Available from: https://www.mciindia.org/documents/faq/ faq-teq.pdf. [Last accessed on 2019 Jul 09].

24. Health Ministry, MCI in a Standoff. The Hindu; 2006. Available from: https://www.thehindu.com/todays-paper/tp-opinion/health-ministrymci-in-a-standoff/article3116862.ece. [Last accessed on 2019 Jul 10].

25. AIIMS: AIIMS AIIMS Doctors Campaign Against Private Medica Colleges. Navbharat Times; 2018. Available from: https://www. navbharattimes.indiatimes.com/metro/delhi/other-news/aiims-doctorscampaign-against-private-medical-colleges/articleshow/65660342. cms. [Last accessed on 2019 Jul 10]

26. Hamed HJ, Amini A, Alizadeh M. Developing Social Accountability Medical Council of India. Minimum Qualifications for Teachers in Medical Institutions Regulations; 1998. Available from https://www. mciindia.org/documents/rulesAndRegulations/Teachers-EligibilityQualifications-Rgulations-1998.pdf. [Last accessed on 2020 Jan 01].

27. World Health Organization. Guidelines for Quality Assurance of Basic Medical Education in the Western Pacific Region. Available from: https:// www.iris.wpro.who.int/bitstream/handle/10665.1/5593/9290610204_ eng.pdf.

28. Gunashekar S, Hackett P, Castle-Clarke S, Rouse R, Grant J. Analysis of research and education indicators to support designation of academic health science centres in England. Rand Health Q 2013;3:2.

29. TB, 82-Quality-Indicators; 2014. Available from: https://www.ouh. nhs.uk/about/trust-board/2014/july/documents/tb2014.82-qualityindicators.pdf. [Last accessed on $2019 \mathrm{Jul} 10$ ].

30. Eye Health Hero: Harsha Bhattacharjee. IAPB. Available from: https:// www.iapb.org/eye-health-heroes/eye-health-heroes-2017/eye-healthhero-harsha-bhattacharjee. [Last accessed on 2019 Jul 14].

31. MD-DNB Equivalence: Setback to DNB Candidates as Supreme Court Dismisses Petition. Medical Dialogues; 2018. Available from: https://www.medicaldialogues.in/md-dnb-equivalence-setback-to-dnbcandidates-as-supreme-court-dismisses-petition. [Last accessed on 2019 Jul 10].

32. Supreme Court of India Record of Proceedings. Sankalp Association of DNB Doctors vs. Union of India. Diary No. 32846; 2017. Available from: https://www.sci.gov.in/supremecourt/2017/32846/32846 2017 order_02-feb-2018.pdf.

33. Eng $\overline{L S}$; 2017. Available from: http://www.164.100.47.4/billstexts/ 1sbilltexts/asintroduced/279_2017_eng_ls.pdf. [Last accessed on 2019 Jul 11].

34. Doctors A of D. Letter to aDrharshvardhan Re: Absolute \#DNBequivalence to MD/MS. DNB can be the Backbone of Med. Education System and Help in Fulfilling the Unmet Need of Teaching Faculty in Medical Colleges if Given Equal Opportunities @MoHFW INDIA@NITIAayog@Amitabhk87@Sujakrao@ RemaNagarajanpic.twitter.com/JrYYQVtvhQ. @Association DNB 2019. Available from: https://www.twitter.com/association dnb/ status/1147905983798108160. [Last accessed on 2019 Jul 11].

35. Medical Council of India. Minimum Qualifications for Teachers in Medical Institutions Regulations; 1998. Available from <https://www. mciindia.org/documents/rulesAndRegulations/Teachers-EligibilityQualifications-Rgulations-1998.pdf $>$. [Last accessed on 2020 Jan 01].

36. Better Late. Indianexpress. Available from: https://www.indianexpress. $\mathrm{com} / \mathrm{article} /$ opinion/editorials/better-late-national-medicalcommission-indian-medical-association-5010563.

37. Why Some Vested Interests have created a Fog around National Medical Commission Bill Economic Times. Available from: https:// www.economictimes.indiatimes.com/news/politics-and-nation/whysome-vested-interests-have-created-fog-around-national-medicalcommission-bill/articleshow/62794948.cms.

38. National Medical Commission Bill tabled in Lok Sabha, the Economic Times. Available from: https://www.economictimes.indiatimes. com/news/politics-and-nation/national-medical-commission-billtabled-in-lok-sabha/articleshow/62295445.cms. [Last accessed on 2019 Jul 11]

39. ANBAI Perseverance Pays off Equivalence Accomplished. PDF. Available from: https://www.anbai.org/pdf/anbai perseverance pays off equivalence accomplished.pdf. [Last accessed on 
2019 Jul 11].

40. Association of DNB Doctors@Association DNB. Available from https://www.twitter.com/association dnb?lang=en

41. Tandon A. DNB Experts to be on Par with MD, MS. Available from https:/www.tribuneindia.com/news/nation/dnb-experts-to-be-on-parwith-md-ms/670864.html.

42. MD-DNB Equivalence: MCI BOG Issues Gazette Notification for new TEQ Rules, Details. Available from: https://www.medicaldialogues.in/ md-dnb-equivalence-mci-bog-issue-gazette-notification-for-new-teqrules-details.

43. Minimum Qualifications for Teachers in Medical Institution Regulations, 1998. Addition of Clause 4A After Sr. No. 4 and Substitution of Clause 6 Vide Notification. Available from: https:// www.mciindia.org/ActivitiWebClient/open/getdocument?path= documents/public/portal/gazette/teq-01.11.2018.pdf. [Last accessed on 2017 Jun 08]

44. Board of Governors in Supersession of Medical Council of India Notification. Available from: https://www.old.mciindia.org/rules-andregulation/gazette\%20notifications\%20-\%20amendments/teq.pdf. Last accessed on 2018 Nov 01].

45. Specialist DNB Disadvantaged with New MCI Equivalence Norms:
NBE, ANBAI Officials Tell MCI; 2019. Available from: https://www. medicaldialogues.in/specialist-dnb-disadvantaged-with-new-mciequivalence-norms-nbe-anbai-officials-tell-mci.

46. DNB Recognised for Appointment of Faculty: MOS Health Tells Parliament on Addressing HR Shortage in Healthcare. Available from: https://www.medicaldialogues.in/dnb-recognised-for-appointment-offaculty-mos-health-on-addressing-human-resource-shortage-in-healthcare.

47. FAQs on National Medical Commission Bill; 2017. Available from https://www.mohfw.gov.in/newshighlights/faqs-national-medicalcommission-bill-2017.

48. The National Medical Commission Act; 2019. Available from: http:/ www.egazette.nic.in/WriteReadData/2019/210357.pdf. [Last accessed on 2019 Aug 08; Last accessed on 2020 Jan 01].

49. Call for Applications for Fellowships and Support to of Medical Colleges Universities Research Institutes for training. Available from: https:// www.namewww.dhr.gov.in/sites/default/files/advertisement $\% 20$ application $\% 20 \mathrm{hrd} \% 20$ Scheme 1.pdf.

50. Medical Council of India dissolved, Replaced with Board of Governors. Available from: https://www.hindustantimes.com/india-news/medicalcouncil-of-india-dissolved-replaced-with-board-of-governors/storyttrwefrkwcgkq3xcg34col.html. 